\title{
Living organisms and sedimentary remains from high mountain lakes in the Alps
}

\author{
Aldo Marchetto, ${ }^{1 *}$ Angela Boggero, ${ }^{1}$ Diego Fontaneto, ${ }^{1}$ Andrea Lami, ${ }^{1}$ André F. Lotter, ${ }^{2}$ Marina M. Manca, ${ }^{1}$ \\ Julieta Massaferro, ${ }^{3}$ Rosario Mosello, ${ }^{1}$ Simona Musazzi, ${ }^{1}$ Ulrike Nickus, ${ }^{4}$ Roland Psenner, ${ }^{5}$ Michela Rogora, ${ }^{1}$ \\ Sanna Sorvari Sundet, ${ }^{6}$ Evzen Stuchlik, ${ }^{7}$ Gabriele A. Tartari, ${ }^{1}$ Hansjoerg Thies, ${ }^{8}$ Monica Tolotti ${ }^{9}$
}

${ }^{1}$ National Research Council, Water Research Institute, Largo Tonolli 50, 28922 Verbania Pallanza (VB), Italy; ${ }^{2}$ Institute of Plant Sciences, Paleoecology, University of Bern, Altenbergrain 21, 3013 Bern, Switzerland; ${ }^{3}$ Programa de Conservación de la Biodiversidad del Parque Nacional Nahuel Huapi, Consejo Nacional de Investigaciones Científicas y Técnicas, Fagnano 244,8400 Bariloche, Argentina; ${ }^{4}$ Department of Atmospheric and Cryospheric Sciences, University of Innsbruck, Innrain 52, 6020 Innsbruck, Austria; ${ }^{5}$ Eurac Research, Drususallee 1, 39100 Bolzano, Italy; ${ }^{6}$ Natural Resources Institute Finland (LUKE), Research Infrastructure Services, Latokartanonkaari 9, 00790 Helsinki, Finland; ${ }^{7}$ Biology Centre CAS, Institute of Hydrobiology, Na Sádkách 702/7, 37005 České Budějovice, Czech Republic; ${ }^{8}$ Institute of Interdisciplinary Alpine Research, Austrian Academy of Sciences, Innrain 25, 6020 Innsbruck, Austria; ${ }^{9}$ Fondazione Edmund Mach, Via Edmund Mach 1, 38098 San Michele all'Adige (TN), Italy

\begin{abstract}
We publish a data set of environmental and biological data collected in 2000 during the ice-free period in high mountain lakes mainly located above the local timberline in the Alps, in Italy, Switzerland and Austria. Environmental data include coordinates, geographical attributes and detailed information on vegetation, bedrock and land use in lake catchments. Chemical analyses of a sample for each lake collected at the lake surface in summer 2000 are also reported. Biological data include phytoplankton, zooplankton, macroinvertebrates, benthic diatoms. Diatoms, cladoceran and chironomids remains and algal and bacterial pigments were also analysed in lake sediments.
\end{abstract}

\section{INTRODUCTION}

Limnology of Alpine lakes dates back to the end of the $19^{\text {th }}$ century, mainly focusing on the presence and composition of benthic and plankton fauna, with a predominantly taxonomic approach in the description of biological diversity (Pero, 1893; Zschokke, 1894; Bourcart, 1906; Pesta, 1912; De Marchi, 1913). Later on, Alpine lakes were used as experimental fields to test general ecological theories (Baldi, 1937; Bossone and Tonolli, 1954), analysing for example life history parameter estimates (Ravera and Tonolli, 1956), seasonal developments of plankton (Ferrari, 1967), and productivity measurements (de Bernardi et al., 1983).

Starting from the 1950's, a number of surveys of the chemical and biological features of Alpine lakes was car-

Corresponding author: aldo.marchetto@cnr.it

Key words: Alpine lakes; diatoms; phytoplankton; zooplankton; benthos; algal pigments.

Received: 24 May 2021

Accepted: 4 August 2021.

This work is licensed under a Creative Commons Attribution NonCommercial 4.0 License (CC BY-NC 4.0).

${ }^{\circ}$ Copyright: the Author(s), 2021

Licensee PAGEPress, Italy

J. Limnol., 2021; 80(3):2036

DOI: 10.4081/jlimnol.2021.2036 ried out. In a pioneering exercise of citizen science, Tonolli and Tonolli (1951) asked alpinists to send lake plankton samples collected with a common protocol and produced an account of the relationships between the biological communities and the main environmental parameters of 170 lakes. Thirty years later, a similar exercise was carried out, including also the examination of net phytoplankton and chemical analysis of lake water of about 300 lakes, 46 of them included in the previous survey (Giussani et al., 1986).

Some further surveys were carried out in the 1990s, collecting and analysing surface sediment samples in order to establish species-environment relationships to be used for inferring past lake condition from the biological remains of specific groups such as diatoms, cladocera, and chironomids found in sediment cores (Marchetto and Schmidt, 1992; Lotter et al. 1997, 1998). In Summer 2000, within the EU-funded programme EMERGE ("European Mountain lake Ecosystems: Regionalisation, diaGnostic \& socio-economic Evaluation") aimed at assessing the status of remote mountain lake ecosystems throughout Europe, chemical, morphological and biological information was collected from a large number of high mountain lakes ( 72 from the Alps), including for the first time both living and sub-fossil components, using common standard protocols, mainly based on the experience of a previous EU-funded programme ("MOLAR, Measuring and modelling the dynamic response of remote mountain lake ecosystems to environmental change: a programme of MOuntain LAke Research"). The collected data refer to living organism and to remains found in surface sediment (assumed to represent the "present" condi- 
tion) and at ca. 10-cm depth, assumed to refer to pre-industrial condition, to allow the identification of changes due to the long-range transport of atmospheric pollutants. The absence in the latter samples of spherical carbonaceous particles, typical of industrial combustion, was used to verify their pre-industrial deposition (Rose et al., 1999).

This large amount of environmental data was used for ecological studies (Marchetto et al., 2009) and can still be useful for long-term comparative analyses, or for developing or testing ecological methods and theories. The aim of this data paper is to gather the massive amount of data collected in 2000 within the EU-funded programme EMERGE for 72 high mountain lakes from the Alps in a formal dataset in order to make it available for its further use by other studies.

Other studies concerning a large number of high mountain lakes were published, treating sedimentary remains (Bigler et al., 2008; Kuefner et al., 2020), living macroinvertebrates (Boggero et al., 2008; Fureder et al., 2006; Boggero and Lencioni, 2006), plankton (Maiolini et al., 2006; Obertegger et al., 2010; Horvath et al., 2016; Tolotti et al., 2018), and benthic diatoms (Feret et al., 2018), as well as literature reviews (Jersabek et al., 2001; Ruffo and Stoch, 2005; Boggero, 2018; Stoch et al., 2019).

\section{METHODS}

The 72 study lakes, mainly located above the timberline, were selected to avoid anthropogenic disturbance in the catchment, for instance by sewage discharge. Their location is shown in Fig. 1. The major direct human impacts affecting these lakes are fish introduction, tourism and alpine pastures within the catchment. In addition, the lakes are subject to the deposition of airborne pollutants, in particular acidifying compounds (sulphur and nitrogen) (The MOLAR Water Chemistry Group, 1999), persistent organic pollutants (POPs) (Grimalt et al., 2001) and heavy metals (Hofer et al., 2001).

Geo-referenced coordinates, geographical attributes and detailed information on vegetation, bedrock and land use in lake catchments were collated for each lake. Water samples were collected at the lake surface, on the vertical of the deepest point, and analysed for $\mathrm{pH}$, conductivity, alkalinity, ammonium, total nitrogen, reactive and total phosphorus, reactive silica, major cations (calcium, magnesium, sodium, potassium) and anions (sulphate, nitrate, chloride), and dissolved organic carbon (DOC). As part of the analytical quality control within each laboratory, a check of the ionic balance was performed and a comparison between measured and calculated conductivity undertaken for all analyses. In lakes with maximum depth 5 $\mathrm{m}$ or less, samples for bacteria and chlorophyll were collected with the top end of the sampler $0.5 \mathrm{~m}$ below lake surface. In the other lakes, samples were collected at 1.5 times the Secchi disk reading, or $0.5 \mathrm{~m}$ or less above the bottom if the Secchi disk reading was $1 \mathrm{~m}$ or less above the bottom. Samples for chlorophyll were filtered through Whatman GF/F filters, kept in cool dark and frozen as soon as possible. Chlorophyll a was measured after gentle

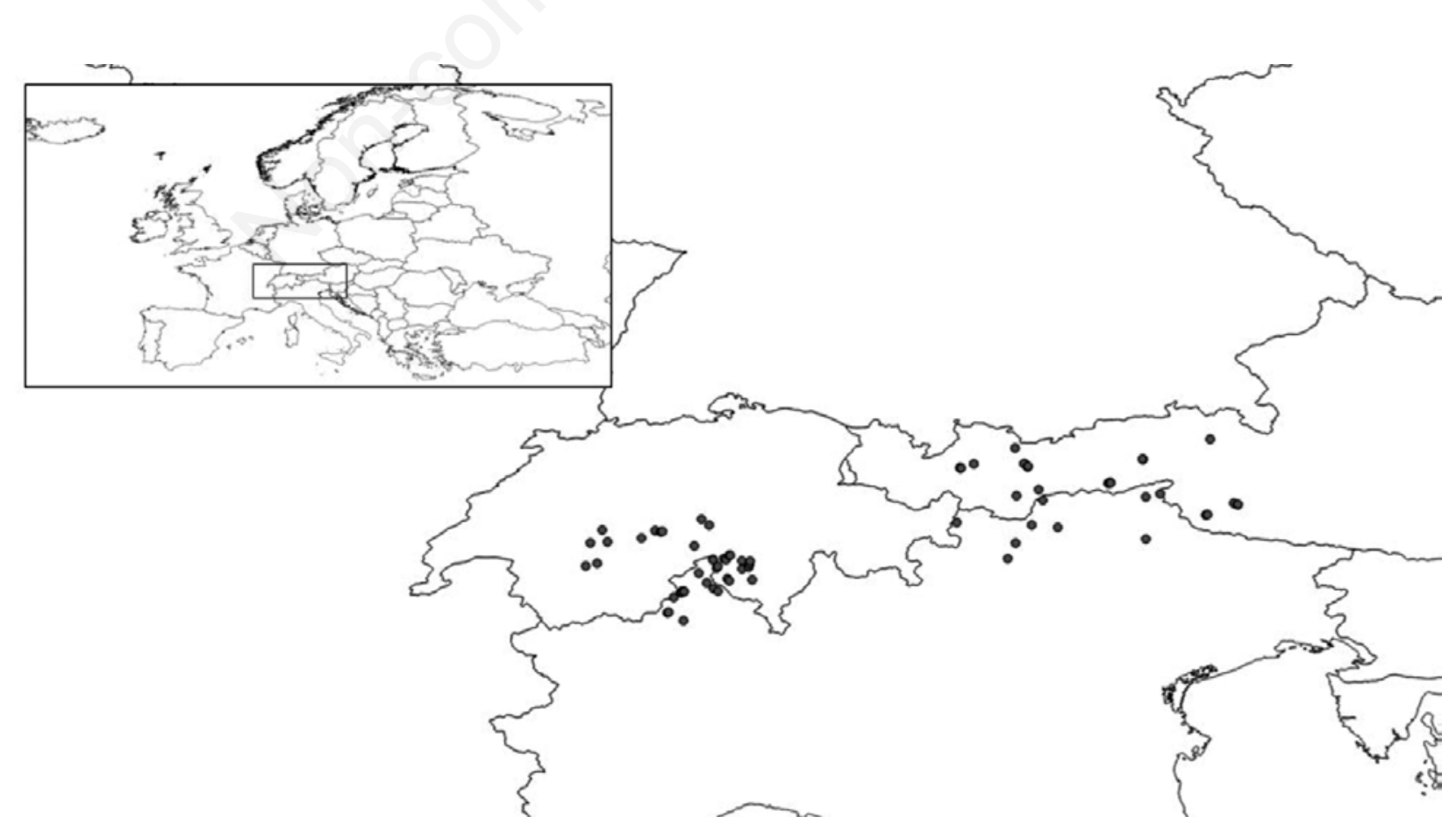

Fig. 1. Location of the sampled lakes. 
filtration and concentration on Whatman GF/F glass fibre filters, extracted in acetone and determined spectrophotometrically or fluorometrically (Wathne and Hansen, 1997). Bacteria were determined from formaldehyde preserved samples (final concentration $2 \% \mathrm{w} / \mathrm{v}$ ) using $0.2 \mu \mathrm{m}$ pore size black polycarbonate filters (Poretics or Nuclepore), DAPI stain and epifluorescence microscopy (Porter and Feig, 1980). Bacterial cells were counted and then sized by image analysis (widths and lengths measured) and their volumes calculated as cylinders with 2 hemispheres (Psenner, 1993).

Lake sampling took place during late summer or early fall according to a common sampling protocol (Fjellheim et al., 2000). Samples were taken from the littoral and sieved through a net with $250 \mu \mathrm{m}$ mesh size, and preserved in $70 \%$ ethanol. In each lake, samples from the range of available habitats were amalgamated to one sample prior to analysis. Benthic animals were identified to species using a binocular and/or a microscope. Chironomid larvae were mounted in Hoyer's solution on microscopic slides and identified to the lowest taxonomic level possible. Most animal groups were identified to the species level. In cases of differences in taxonomic precision between the participating institutions, the highest taxonomic level was chosen to facilitate comparison between regions (Schnell et al., 1999).

Phytoplankton samples were collected through Ruttner or Patalas bottles, $1 \mathrm{~m}$ below Secchi depth or $1 \mathrm{~m}$ above the bottom in those lakes where the Secchi disk was still visible on the bottom. Samples were then fixed in Lugol's solution. Counting, measuring and taxonomic determination were performed in sedimentation chambers under the inverted microscope following Utermöhl (1958). Zooplankton samples were taken by several vertical hauls in proximity to the deepest point of the lake, using a $200 \mu \mathrm{m}$ plankton net for quantitative samples. Samples were preserved in $4 \%$ formaldehyde or in ethanol. Taxonomy mainly followed Smirnov (1974, 1996), Kiefer (1978), Margaritora (1985), Einsle (1993), and Flößner (2000) for planktonic crustaceans.

Epilithic diatom samples were collected by brushing 10-12 small stones from 3 points around the lake, less than 1-m deep. They were then fixed in Lugol's iodine solution and mounted in Naphrax. Diatoms were analysed using a microscope at 1000x magnification and identified to species level. Diatom taxonomy mainly followed Krammer and Lange-Bertalot (1986, 1988, 1991a, 1991b). Sediment samples for cladocerans, chironomids, diatoms and pigment analyses were collected using a gravity corer and sliced in the field. The top $0.5 \mathrm{~cm}$ of each core was used as the surface sediment sample to represent the current condition, while a second sample at ca. $10-15 \mathrm{~cm}$ of depth was used as the "pre-industrial" sample. For diatom analysis, about $10 \mathrm{mg}$ of sediment was cleaned using standard techniques (Renberg, 1990) and counted under oil immersion at a magnification of 1000x. Diatom taxonomy mainly followed Krammer and Lange-Bertalot (1986, 1988, 1991a, 1991b). The samples for pigment analysis were preserved deepfrozen until the analysis. A sub-sample of ca $2 \mathrm{~g}$ wet sediment was weighed and extracted overnight with ca. 10 $\mathrm{mL}$ of an acetone/water mixture (90:10). The extract was then centrifuged at $3000 \mathrm{rpm}$ for $10 \mathrm{~min}$ in a glass centrifuge tube and used for total pigment and for specific chlorophyll and carotenoid determinations through HPLC chromatography following Lami et al. (1994).

Cladoceran sub-fossil remains were counted in ca. 3 $\mathrm{g}$ of wet sediment. The samples were deflocculated in warm $10 \% \mathrm{KOH}$ for 2 hours and then digested in $10 \%$ $\mathrm{HCl}$ (Frey, 1986) or freeze-dried sediment was heated to boiling point in $50 \mathrm{~mL}$ of $10 \% \mathrm{KOH}$ for about $30 \mathrm{~min}$, being continuously mixed with a magnetic stirrer (Frey, 1958 modified according to Prażáková and Fott, 1994). Cool samples were filtered through a phosphorus-bronze sieve (mesh-size $40 \mu \mathrm{m}$ ), washed with water, and transferred into a mixture of glycerine, $70 \%$ ethanol and chlorazol black (Schmid et al., 1998). Chydorid remains were determined according to Smirnov $(1974,1996)$, Margaritora (1985), Frey (1986) and Floßner (2000). At least 200 remains were counted and identified following Frey $(1958,1960)$ at magnifications between 100 and 200x. Several different cladoceran remains were identified, namely postabdominal claws, ephippia, head shields, postabdomens, valves, and their number were combined in order to obtain a minimum number of animals per sample following Frey (1986).

Chironomid analyses were performed following Hofmann (1986) and Warwick (1980). From each sample, 5$15 \mathrm{~g}$ wet sediment was deflocculated with hot $\mathrm{KOH}$ $(10 \%)$ for 45 minutes. The remains of each section (previously sieved through 280,200 and $150 \mu \mathrm{m}$ mesh size) were picked out and mounted with Canada balsam for microscopic identification.

Alternatively, chironomid head capsules were obtained by sieving the sediment through a $90 \mu \mathrm{m}$ screen after deflocculating with hot $10 \% \mathrm{KOH}$ for $15 \mathrm{~min}$. The head capsules were hand sorted from a Bolgorov tray with forceps under the 40x magnification of a stereoscopic microscope. The capsules were then mounted in Euparal medium after dehydration with absolute ethanol. Taxa were determined mainly following Schmid (1993) and Rieradevall and Brooks (2001). Only some of the chironomids were identified to the species level; others were identified only to genus or, in a few cases, tribe or subfamily.

For all biological analysis, taxonomic consistence was obtained through discussion among taxonomists in specific project workshops. 


\section{RESULTS}

\section{Data set description}

This data set includes biotic and abiotic information from 72 lakes in the Alps, ordered in the following 10 sheets, gathered together into an Excel file:

i. Location and morphometry (of the lakes), described in Tab. 1;

ii. Water chemistry, containing five columns: Lake ID
(Tab. 1), compound name, compound code, value, unit.

iii. Phytoplankton counts, containing five columns: Lake ID (Tab. 1), taxon code, taxon name, division, and percent abundance;

iv. Zooplankton counts, containing seven columns: Lake ID (Tab. 1), taxon code, species name, authorship, AphiaID (Worms Editorial Board, 2021), group, percent abundance;

v. Epilithic diatoms, containing four columns: Lake ID

Tab. 1. Content of the sheet "Location and morphometric characteristics of the lakes".

\begin{tabular}{|c|c|c|c|}
\hline Column name & Content & Unit & Data type \\
\hline LakeID & Lake identifier & & Text \\
\hline LakeName & Lake name & & Text \\
\hline Lat & Latitude N WGS84 & Degree & Floating \\
\hline Lon & Longitude E WGS84 & Degree & Floating \\
\hline Alt & Lake altitude & $\mathrm{m}$ above sea level & Integer \\
\hline C_area & Catchment area & Hectares & Floating \\
\hline GeolMet & Metamorphic rocks in catchment & Percent & Floating \\
\hline GeolPlut & Plutonic rocks in catchment & Percent & Floating \\
\hline GeolVolc & Volcanic rocks in catchment & Percent & Floating \\
\hline GeolDet & Detrital rocks in catchment & Percent & Floating \\
\hline GeolCarb & Carbonate rocks in catchment & Percent & Floating \\
\hline Glaciers & Catchment glaciated & Percent & Floating \\
\hline GeolGlac & Glacial deposits rocks in catchment & Percent & Floating \\
\hline Bare & Bare ground in catchment & Percent & Floating \\
\hline Moorland & Moorland in catchment & Percent & Floating \\
\hline Peat & Peat in catchment & Percent & Floating \\
\hline Meadow & Meadow in catchment & Percent & Floating \\
\hline Shrubs & Shrubs in catchment & Percent & Floating \\
\hline Con_wood & Coniferous woodland in catchment & Percent & Floating \\
\hline Dec_wood & Deciduous woodland in catchment & Percent & Floating \\
\hline Rural & Rural area in catchment & Percent & Floating \\
\hline Max_Alt & Maximum catchment altitude & $\mathrm{m}$ above sea level & Integer \\
\hline Chain & Position of lake in chain & From top to bottom & Integer \\
\hline L_area & Lake area & Hectares & Integer \\
\hline Depth & Maximum Lake Depth & $\mathrm{m}$ & Floating \\
\hline Lit_Rock & Littoral zone that is rocky & Percent & Integer \\
\hline Lit_sand & Littoral zone that is sandy & Percent & Integer \\
\hline Lit_Org & Littoral zone that is organic & Percent & Integer \\
\hline Inlet & Presence of an inflow stream & true $=1$ & Logical \\
\hline Outlet & Presence of a lake outflow stream & true $=1$ & Logical \\
\hline Seepage & Whether the lake is a seepage lake & true $=1$ & Logical \\
\hline Resid & Calculated residence time & Years & Floating \\
\hline Secchi & Secchi Disc Depth & m $(-9999=$ bottom $)$ & Floating \\
\hline Bacteria & Total bacteria biomass & $\mu \mathrm{g} \mathrm{C} \mathrm{L}{ }^{-1}$ & Floating \\
\hline ChlConc & Concentration of chl a & $\mu g \mathrm{~L}^{-1}$ & Floating \\
\hline Fish & Fish Presence & Yes/no/unknown & Text \\
\hline IceCover & Ice cover length & Days & Integer \\
\hline
\end{tabular}


(Tab. 1), taxon code, taxon name, and percent abundance;

vi. Littoral macroinvertebrates, containing five columns: Lake ID (Tab. 1), taxon code, Taxon name, order and relative abundance;

vii. Sedimentary cladoceran (remains), containing seven columns: Lake ID (see Tab. 1), depth into the sediment (in $\mathrm{cm}$ ), taxon code, taxon name, AphiaID (Worms Editorial Board, 2021), remain, remains per gram of dry sediment;

viii. Sedimentary diatoms, containing five columns: Lake ID (Tab. 1), depth into the sediment (in $\mathrm{cm}$ ), taxon code, taxon name, and percent abundance;

ix. Sedimentary chironomids, containing five columns: Lake ID (Tab. 1), depth into the sediment (in $\mathrm{cm}$ ), taxon code, taxon name, and percent abundance;

x. Sedimentary (algal and bacterial) pigments containing six columns: Lake ID (Tab. 1), depth into the sediment (in $\mathrm{cm}$ ), compound name, compound code, value, unit.

Taxon names consist of the original species name, as given in 2000, and they were not updated, but in each sheet, diatom synonyms were merged, when present

In some cases, in particular for living phytoplankton and some macroinvertebrates, identification at the species level was not possible and "sp.", "gr.", "indet." were reported.

Not all organisms were collected in every lake. The number of lakes, taxa and relative abundance values included in each file are reported in Tab. 2 .

\section{Data set information}

Object name: Living organisms and sedimentary remains from high mountain lakes in the Alps.

Data set citation: EMERGE Alpine lakes

Format name: xlsx, Excel file

Distribution (permanent link): https://zenodo.org/record/ 5205468
Date of creation: 26 January 2021

Date of last revision: 16 August 2021

Date of publication: 16 August 2021

Update policy: not updated

Language: English

License of use: the access and the use are free. Data set authors would appreciate users providing a link to the original data set, and a citation to the present paper, or to be included as co-author in a new paper.

Metadata language: English

Metadata managers: Aldo Marchetto (aldo.marchetto@ cnr.it)

Project title: Living organisms and sedimentary remains from high mountain lakes in the Alps.

Database manager: Aldo Marchetto

Temporal coverage: Summer 2000

Funding grants: European Union, EMERGE Project (contract No. EVK1-CT-1999-032)

Study area: mountain lakes in the Alps with surface standing waters showing areas greater than 0.1 ha $(0.001$ $\mathrm{km}^{2}$ ), maximum depth greater than $1 \mathrm{~m}$, at mean water level, placed in proximity of or above the tree line. The latter is a non-linear wavy line between the subalpine and the alpine areas, drawn based on treegrowth limiting factors (Körner, 1998).

Bounding box:

Min longitude: 7.40 - max longitude: 12.77

Min latitude: 45.94 - max latitude: 47.43

Min altitude: 1592 - max altitude: $2796 \mathrm{~m}$ asl

Sampling design: One sampling activity during the icefree period 2000

Habitat type: Natural lakes (i.e., lakes without anthropogenic infrastructures)

Biogeographical region: Alpine (EEA, 2002)

Countries: Austria, Italy and Switzerland

Quality control for geographic data: coordinates were collected by GPS during sampling and verified on topographic maps.

Tab. 2. Number of data.

\begin{tabular}{llccc} 
Data sheet & N. of lakes & N. of taxa or variables & N. of data \\
1. & Location and morphometry & 72 & 35 & 2496 \\
\hline 2. & Water chemistry & 71 & 15 & 971 \\
\hline 3. & Phytoplankton counts & 46 & 284 & 843 \\
\hline 4. & Zooplankton counts & 52 & 28 & 235 \\
\hline 5. & Epilithic diatoms & 71 & 68 & 1256 \\
\hline 6. & Littoral macroinvertebrates & 58 & 45 & 508 \\
\hline 7. & Sedimentary cladocerans & 68 & 37 & 1064 \\
\hline 8. & Sedimentary diatoms & 70 & 349 & 2983 \\
\hline 9. & Sedimentary chironomids & 20 & 48 & 248 \\
\hline 10. & Sedimentary pigments & 70 & 64 & 7121 \\
\hline
\end{tabular}


Taxonomic coverage: phytoplankton, zooplankton, macroinvertebrates, diatoms.

Taxon specialist: Consistency of the taxonomy in the data set was granted by taxonomic workshops during the EMERGE and MOLAR projects.

Quality control for taxonomic data: before publication of the data set, algal taxon spelling and authorship were verified using Algaebase: Listing of World's Algae (Guiry and Guiry, 2021). The same control was performed on macroinvertebrates and zooplankton using Fauna Europea (De Jong et al., 2014) and WoRMS, the World Register of Marine Species (WoRMS Editorial Board, 2021).

\section{CONCLUSIONS}

The present dataset covers a wide variety of information from abiotic (morphological, geographic, physical, chemical) to biotic (plankton, benthos, diatoms, sedimentary remains) unique in its kind and format. Following the tradition of leaving data collected in mountain lakes to free access started by Tonolli and Tonolli (1951) and Giussani et al. (1986), we agreed to publish the EMERGE Alpine data set in the present form in order to share knowledge acquired on high altitude lakes for a better understanding of the functioning of these ecosystems under threat due to global climate change and other anthropogenic impacts.

\section{ACKNOWLEDGMENTS}

This research was partially funded by the European Union, through the EMERGE Project (contract No. EVK1-CT-1999-0032). We would like to acknowledge the following colleagues involved in field work and analysis: Michele Armiraglio, Alberto Barbieri, Maria Grazia Barbieri, Cristiana Callieri, Pierluigi Cammarano, Elzbieta Dumnicka, Renate Ettinger, Josef Franzoi, Leopold Fuereder, Joan Grimalt, Piero Guilizzoni, Beatrice Jann, Gloria Lacort, Giuseppe Morabito, Rosario Mosello, Werner Muller, Elber Huerlimann Niederberger, Arianna Orrù, Pierisa Panzani, Benjamin Pina, Alfredo Pranzo, Gunnar Raddum, Neil Rose, Oyvind Schnell, Marco Simona, Vera Straskrabova, Danilo Tait, Berta Thaler, Mauro Veronesi, Markus Zeh.

\section{REFERENCES}

Baldi E, 1937. [Ricerche biologiche sugli alti laghi della Valsesia. I: I laghetti delle Pisse].[Article in Italian]. Monogr. Comit. Sci. CAI 1:7-38.

Bigler C, Heiri O, Krskova R, Lotter AF, Sturm M, 2008. Distribution of diatoms, chironomids and cladocera in surface sediments of thirty mountain lakes in south-eastern Switzerland. Aquat. Sci. 68:154-171.
Boggero A, 2018. Macroinvertebrates of Italian mountain lakes: a review. Redia 101:35-45.

Boggero A, Fureder L, Lencioni V, Simcic T, Thaler B, Ferrarese U, Lotter A, Ettinger R, 2008. Littoral chironomid communities of Alpine lakes in relation to environmental factors. Hydrobiologia 562:145-165.

Boggero A, Lencioni V, 2006. Arch. Hydrobiol. 165:37-61.

Bossone A, Tonolli V, 1954. [Il problema della convivenza di Arctodiaptomus bacillifer (Koelb), Acantodiaptomus denticornis (Wierz) e di Heterocope saliens Lill].[Article in Italian]. Mem. Ist. Ital. Idrobiol. 8:81-94.

Bourcart FE, 1906. [Les lacs alpine suisses, étude chimique et physique].[Book in French]. George et Cie, Genève: 127 pp.

de Bernardi R, Brogi M,Origgi I, 1983. [Dinamica di popolazione e predazione di Arctodiaptomus alpinus in due laghi alpini di alta quota: Laghi Boden, Alta Val Formazza, m. 2340 s.l.m. ].[Article in Italian]. Proceedings V Congress A.I.O.L. p. 407-416.

de Jong Y, Verbeek M, Michelsen V, de Place Bjørn P, Los W, Steeman F, Bailly N, Basire C, Chylarecki P, Stloukal E, Hagedorn G, Wetzel FT, Glöckler F, Kroupa A, Korb G, Hoffmann A, Häuser C, Kohlbecker A, Müller A, Güntsch A, Stoev P, Penev L, 2014. Fauna Europaea - all European animal species on the web. Biodiv. Data J. 2:e4034.

De Marchi M, 1913. [Streblocerus serricaudatus nel Trentino]. [Article in Italian]. Atti Soc. ital. Sc. Nat. 51:107-216.

EEA (European Environment Agency), 2002. Europe's biodiversity - biogeographical regions and seas. EEA Report No $1 / 2002$

Einsle U, 1993. [Crustacea Copepoda Calanoida und Cyclopoida. Süsswasserfauna von Mitteleuropas. Band 8/4-1].[Book in German]. Gustav Fischer Verlag, Stuttgart.

Feret L, Bouchez A, Rimet F, 2017. Benthic diatom communities in high altitude lakes: a large scale study in the French Alps. Ann. Limnol. 53:411-423.

Ferrari I, 1967. [Accrescimento individuale e ciclo stagionale della Daphnia middendorffiana di un lago alpino].[Article in Italian]. Mem. Ist. ital. Idrobiol. 26:41-83.

Fjellheim A, Raddum GG, Schnell ØA, 2000. EMERGE - protocol for the sampling of contemporary invertebrates. - European Mountain lake Ecosystems: Regionalisation, diaGnostics \& socio-economic Evaluation (EMERGE), protocol 06. University College London. Available from: http://www.mountain-lakes.org/emerge/www.mountainlakes.org/emerge/methods/06.pdf

Flößner D, 2000. [Die Haplopoda und Cladocera (ohne Bosminidae) Mitteleuropas].[Book in German].

Frey DG, 1958. The late-glacial cladoceran fauna of a small lake. Arch. Hydrobiol. 54: 209-275.

Frey DG, 1960. The ecological significance of cladoceran remains in lake sediments. Ecology 41:684-698.

Frey DG, 1986. Cladocera analysis, p. 677-692. In: B.E. Berglund (ed.), Handbook of Holocene Palaeoecology and Palaeohydrology. J. Wiley \& Sons, Chichester.

Fureder L, Ettinger R, Boggero A, Thaler B, Thies H, 2016. Macroinvertebrate diversity in alpine lakes: Effects of altitude and catchment properties. Hydrobiologia 562:123-144.

Giussani G, de Bernardi R, Mosello R, Origgi I, Ruffoni T, 1986. [Indagine limnologica sui laghi alpini d'alta quota].[Book in Italian]. Doc. Ist. ital. Idrobiol. 9:415. 
Grimalt JO, Fernandez P, Berdié L, Vilanova RM, Catalan J, Psenner R, Hofer R, Appleby PG, Rosseland BO, Lien L, Massabuau JC, Battarbee RW, 2001. Selective trapping of organochlorine compounds in mountain lakes of temperate areas. Environ. Sci. Technol. 35:2690-2697.

Guiry MD, Guiry GM, 2021. AlgaeBase. World-wide electronic publication, National University of Ireland, Galway. Accessed: 24 February 2021. Available from: https:/www.algaebase.org

Hofer R, Lackner R, Kargl J, Thaler B, Tait D, Bonetti L, Vistocco R, Flaim G, 2001. Organo-chlorine and metal accumulation in fish (Phoxinus phoxinus) along a north-south transect in the Alps. Water Air Soil Poll. 125:189-200.

Hofmann W, 1986. Chironomid analysis, p. 715-717. In: B.E. Berglund (ed.), Handbook of Holocene Palaeoecology and Palaeohydrology. J. Wiley \& Sons, Chichester.

Horvath Z, Vad CF, Preiler C, Birtel J, Matthews B, Ptacnikova R, Ptacnik R, 2016. Zooplankton communities and Bythotrephes longimanus in lakes of the montane region of the northern Alps. Inland Waters 7:3-13.

Jersabek CD, Brancelj A, Stoch F, Schabetsberger R, 2001. Distribution and ecology of copepods in mountainous regions of the Eastern Alps. Hydrobiologia 453:309-324.

Kiefer F, 1978. [Das Zooplankton der Binnengewässer].[Book in German]. E. Schweizerbart'sche Verlagsbuchhandlung, Stuttgart.

Krammer K, Lange-Bertalot H, 1986. [Bacillariophyceae. 1. Teil: Naviculaceae. Susswasserflora von Mitteleuropa].[Book in German]. Gustav Fischer Verlag, Stuttgart.

Krammer K, Lange-Bertalot H, 1988. [Bacillariophyceae. 2. Teil: Epithemiaceae. Susswasserflora von Mitteleuropa].[Book in German]. Gustav Fischer Verlag, Stuttgart.

Krammer K, Lange-Bertalot H, 1991a. [Bacillariophyceae. 3. Teil: Centrales, Fragilariaeae, Eunotiaceae. Susswasserflora von Mitteleuropa].[Book in German]. Gustav Fischer Verlag, Stuttgart.

Krammer K, Lange-Bertalot H, 1991b. [Bacillariophyceae.4. Teil: Achnanthaceae. Kritische Erganzungen zu Navicula (Lineolatae) und Gomphonema. Susswasserflora von Mitteleuropa].[Book in German]. Gustav Fischer Verlag, Stuttgart.

Kuefner W, Hofmann A, Ossyssek S, Dubois N, Geist J, Raeder U, 2020. Composition of highly diverse diatom community shifts as response to climate change: A down-core study of 23 central European mountain lakes. Ecol. Ind. 117:106590.

Körner C, 1998. A re-assessment of high elevation treeline positions and their explanation. Oecologia 115:445-459.

Lami A, Marchetto A, Guilizzoni P, Giorgis A, Masaferro J, 1994. Paleolimnological records of carotenoids and carbonaceous particles in sediments of some lakes in Southern Alps. Hydrobiologia 273:57-64.

Lotter AF, Birks HJB, Hofmann W, Marchetto A, 1997. Modern diatom, cladocera, chironomid and chrysophyte cyst assemblages as quantitative indicators for the reconstruction of past environmental conditions in the Alps. I. Climate. J. Paleolimnol. 18:395-420.

Lotter AF, Birks HJB, Hofmann W, Marchetto A, 1998. Modern diatom, cladocera, chironomid, and chrysophyte cyst assemblages as quantitative indicator for the reconstruction of past environmental conditions in the Alps. II. Nutrients. J. Paleolimnol. 19:443-463.
Maiolini B, Lencioni V, Boggero A, Thaler B, Lotter A, Rossaro B, 2016. Zoobenthic communities of inlets and outlets of high altitude Alpine lakes. Hydrobiologia 562:217-229.

Margaritora FG, 1985. [Fauna d'Italia. Cladocera].[Book in Italian]. Calderini, Bologna.

Marchetto A, Rogora M, Boggero A, Musazzi S, Lami A, Lotter AF, Tolotti M, Thies H, Psenner R, Massaferro J, Barbieri A, 2009. Response of Alpine lakes to major environmental gradients, as detected through planktonic, benthic and sedimentary assemblages. Adv. Limnol. 62:419-440.

Marchetto A, Schmidt R, 1992. A regional calibration data set to infer lakewater $\mathrm{pH}$ from sediment diatom assemblages in alpine lakes. Mem. Ist. ital. Idrobiol. 51:115-126.

Obertegger U, Thaler B, Flaim G, 2010. Rotifer species richness along an altitudinal gradient in the Alps. Global Ecol. Biogeogr. 19:895-904.

Pesta O, 1912. [Hochgebirgsseen und ihre Fauna. I].[Article in German]. Verh. Zool. Bot. Ges. Wien 62:158-171.

Pero P, 1893. [Ricerche e studi sui laghi valtellinesi].[Article in Italian]. Nuova Notarisia 4.

Prażáková M, Fott J, 1994. Zooplankton decline in the Černé lake (Šumava Mountains, Bohemia) as reflected in the stratification of cladoceran remains in the sediment. Hydrobiologia 274:121-126.

Porter KG, Feig YS, 1980. The use of DAPI for identifying and counting aquatic microflora. Limnol. Oceanogr. 25:943-947.

Psenner R, 1993. Determination of size and morphology of aquatic bacteria by automated image analysis, p. 339-345. In: P. Kemp, B. Sherr, E. Sherr and J. Cole (eds.), Handbook of methods in aquatic microbial ecology. Lewis Publishers, Boca Raton.

Ravera O, Tonolli V, 1956. Body size and number of eggs in diaptomids, as related to water renewal in mountain lakes. Limnol. Oceanogr. 1:118-122.

Remberg I, 1990. A procedure for preparing large sets of diatom slides from sediment cores. J. Palolimnol. 4 87-90.

Rieradevall M, Brooks SJ, 2001. An identification guide to subfossil Tanypodinae larvae (Insecta: Diptera: Chironomidae) based on cephalic setation. J. Paleolimnol. 25:81-99.

Rose NL, Harlock S, Appleby P-G, 1999. The spatial and temporal distributions of spheroidal carbonaceous fly-ash particles (SCP) in the sediment records of European mountain lakes. Water Air Soil Poll. 113:1-32.

Ruffo S, Stoch F, 2005. [Checklist e distribuzione della fauna italiana].[Book in Italian]. Memorie del Museo Civico di Storia Naturale di Verona, Sezione Scienze della Vita 16:309.

Schnell ØA, Rieradevall M, Granados I, Hanssen O, 1999. A chironomid taxa coding system for use in ecological and palaeoecological databases. NIVA Report 3710-97, NIVA, Oslo: $32 \mathrm{pp}$.

Schmid PE, 1993. A key to the larval Chironomidae and their instars from the Austrian Danube region streams and rivers. Part 1: Diamesinae, Prodiamesinae and Orthocladiinae. Wasser Abwasser Supplement 3/93:514 pp.

Smirnov NN, 1974. Chydoridae of the World. USSR Fauna, 101. Nauka, Leningrad: $531 \mathrm{pp}$.

Smirnov NN, 1996. Cladocera: The Chydorinae and Saycinae (Chydoridae) of the World. Guides to the identification of the microinvertebrates of the Continental waters of the World. 11. SPB Academic Publishing, The Hague. 
Stoch F, Vagaggini D, Margaritora FG, 2019. Macroecological and spatial patterns in the distribution of cladocerans in Alpine lakes. Limnetica 38:119-136.

The MOLAR Water Chemistry Group, 1999. The MOLAR Project: atmospheric deposition and lake water chemistry. J. Limnol. 58:88-106.

Tolotti M, Manca M, Angeli N, Morabito G, Thaler B, Rott E, Stuchlik E, 2018. Phytoplankton and zooplankton associations in a set of Alpine high altitude lakes: Geographic distribution and ecology. Hydrobiologia 562:99-122.

Tonolli V, Tonolli L, 1951. [Osservazioni sulla biologia ed ecologia di 170 popolamenti zooplanctonici di laghi italiani di alta quota].[Article in Italian]. Mem. Ist. ital. Idrobiol. 16:21-25.
Utermohl H, 1958. [Zur Vervollkommung der quantitativen Phytoplankton-methodik].[Article in German]. Mitt. Intern. Verh. Internat. Verein. Theor. Angew. Limnol. 9:39.

Warwick WF, 1980 Palaeolimnology of the Bay of Quinte, lake Ontario: 2800 years of cultural influence. Can. Bull. Fish. Aquatic. Sci. 206:1-117.

Wathne BM, Hansen HE, 1997. MOLAR Project Manual, NIVA report no. 0-96061. NIVA, Oslo: 176 pp.

WoRMS Editorial Board, 2021. World Register of Marine Species. Accessed: 19 Apr 2021. Available from https://www.marinespecies.org

Zschokke F, 1894. [Die Tierwelt der Jurasee].[Article in German]. Revue Suisse Zool. 2:349-376. 